\title{
The Four National Taps of Singapore: A Holistic Approach to Water Resources Management from Drainage to Drinking Water
}

\author{
K. N. Irvine, L. H. C. Chua and Hans S. Eikass
}

\begin{abstract}
Water resources in Singapore are managed following the principles of a closed loop hydrologic cycle by one agency, the Public Utility Board (PUB), which promotes its management philosophy through the Four National Taps of Singapore program. The four national taps are: water from local catchment areas; imported water (from Malaysia); reused water (known as NEWater); and desalinated water. Given the uncertainty of water imports, the remaining three national taps have become increasingly important and this paper begins with a general overview of the innovative programs implemented by PUB in support of these three taps. Stormwater runoff is captured from two-thirds of Singapore's land area and stored in reservoirs for subsequent use. Stormwater management is an important component of the catchment area tap and extensive low impact development (LID) implementation has become a priority through the ABC (Active, Beautiful, Clean) Waters Program. Examples of several ABC Waters projects are discussed. NEWater currently supplies 30\% of the country's demand and this is projected to increase to $50 \%$ by 2060 . NEWater plants take treated wastewater through the additional steps of microfiltration, reverse osmosis and ultraviolet treatment for use primarily in industry, although a portion also is blended into the municipal reservoirs. Singapore's single desalination plant currently meets $10 \%$ of its demand, with a second plant to be completed in 2013 that will more than double production. Also discussed are the results of recently completed pilot projects related to stormwater management including testing of $E$. coli in runoff from high density residential areas, a blind taste test and survey on acceptance of NEWater, and a survey of Singaporean understanding about stormwater management issues.
\end{abstract}

Keywords: water supply, LID-BMP, water quality, stormwater, water treatment.

\section{Introduction}

Much has been written about the Singaporean economic miracle (e.g. Huff 1987; Krugman 1994; Chang 2003; Goh 2005; Siddiqui 2010) but less well known, at least in North America, is the innovative approach that Singapore has taken towards water resource management. As such, the objectives of this paper are:

1. Outline Singapore's closed loop, integrated systems approach to water management, locally known as the Four National Taps, explaining why the approach was implemented and factors that have led to its success;

2. Review the diversity of low impact development (LID) technologies implemented as part of the Four National Taps, including a discussion of technology performance; and

3. Summarize preliminary findings of some pilot studies undertaken by students at the National Institute of Education, Nanyang Technological University, related to Singaporean acceptance of NEWater, their understanding of stormwater issues, and stormwater runoff quality characteristics.

\section{Background to the Current Situation in Singapore}

\subsection{History, Politics and Policy Development}

To fully appreciate the current, innovative path that Singapore has pursued with respect to water management it is important first to have a quick overview of Singapore's recent history and associated politics. The first permanent settlement on the island appears to have been established in the late thirteenth century, but the Lieutenant-Governor of Bencoolen (now Bengkulu) in Sumatra, Sir Thomas Stamford Raffles, is credited with establishing the current city-state in 1819. Raffles had been tasked with establishing a port of call as British traders needed a strategic location to provision their merchant fleet sailing between India and China, and a strong foothold was desired to counter the Dutch presence in the region (Turnbull 1980; Murfett et al. 1999). Soon, the island's policy of free trade, as opposed to the restricted trade practiced by the Dutch and Spanish (Trocki 2006), attracted merchants from all over Asia and from as far away as the United States and the Middle East. The early beginnings of multiculturalism were established, and this tradition carries on today with predominant ethnicities being Chinese (74.1\%), Malay (13.3\%),

Irvine, K., L. Chua and H.S. Eikass. 2014. "The Four National Taps of Singapore: A Holistic Approach to Water Resources Management from Drainage to Drinking Water." Journal of Water Management Modeling C375. doi: 10.14796/JWMM.C375.

(c) CHI 2014 www.chijournal.org ISSN: 2292-6062 
Indian (9.2\%), and others (including Europeans, 3.3\%) (Singapore Demographic Bulletin, April 2012, http://www.ica.gov.sg/data/ resources/docs/Media\%20Releases/SDB/SDB_April\%202012.pdf). From 1824 through 1942 Singapore operated under British colonial rule, as Singapore was ceded in perpetuity to the East India Company by the Sultan of Johor (part of present day Malaysia).

On 15 February 1942 Singapore fell to Japan and was under Japanese rule until the end of World War II, at which time Britain regained control. However, the political climate in Southeast Asia was not the same after World War II (Ismail 2012) and Britain, facing post-war economic challenges and conflicting sentiment about colonial policy, granted the federated states of Malaya independence in 1957. By 1959 Singapore, under the leadership of Lee Kuan Yew and the People's Action Party (PAP), was granted internal self government and subsequently joined the federated states of Malaya (now peninsular Malaysia), Sarawak and Sabah (eastern islands of Malaya) to form Malaysia in 1963. This union was short-lived, however, due to political differences, and Singapore was asked to leave, becoming an independent republic in 1965 (Liu et al. 2002). Interestingly, it was around this time (1961 and 1962) that the Johor water agreements were signed, which provided up to $350 \mathrm{mgd}\left(15.3 \mathrm{~m}^{3} / \mathrm{s}\right)$ of raw water to Singapore from Malaysia (Ong 2010).

The beginning of an independent Singapore republic was marked by the visionary leadership of Lee Kuan Yew, Singapore's first Prime Minister (1965-1990) (Oei 1998; Ang 2013). Low (2011) asserts that Lee's focused initiatives to green Singapore have made good business sense by reducing pollution and cutting business costs. The Garden City was aptly named as its welldeveloped network of linked greenways and parks evolved from Lee's first greening program, Tree Planting Day (Tan 2006). Joshi et al. (2012) documented the steps towards the successful cleanup of the Singapore River between 1977 and 1986, emphasizing that Lee's vision required close coordination between government agencies and different sectors in Singapore, and a holistic approach to urban development, environmental management, sustainability and economic opportunity.

As part of Lee's holistic approach to urban environmental management, the Public Utility Board (PUB) was established in 1963 , initially to oversee the provision of electricity, water and piped gas (Khoo 2009). After a significant involvement with the Singapore River restoration, which also prompted the development of separate storm and sanitary sewer systems, PUB relinquished its mandate to manage electrical supply in 2001. This marked the beginning of the Four National Taps water management strategy.

\subsection{The PUB Philosophy of Water Resources Management}

Singapore takes a holistic approach to managing its water resources, essentially overseeing the entire hydrologic cycle through one agency, PUB. PUB has termed this approach closing the loop and the philosophy is summarized in Figure 1. The core element of the closing the loop philosophy is the Four National Taps, or the four water supply sources for Singapore:

1. Imported water from Malaysia;

2. NEWater (recycled water);

3. Water desalination; and

4. Local catchments (i.e. stormwater runoff) and reservoirs.

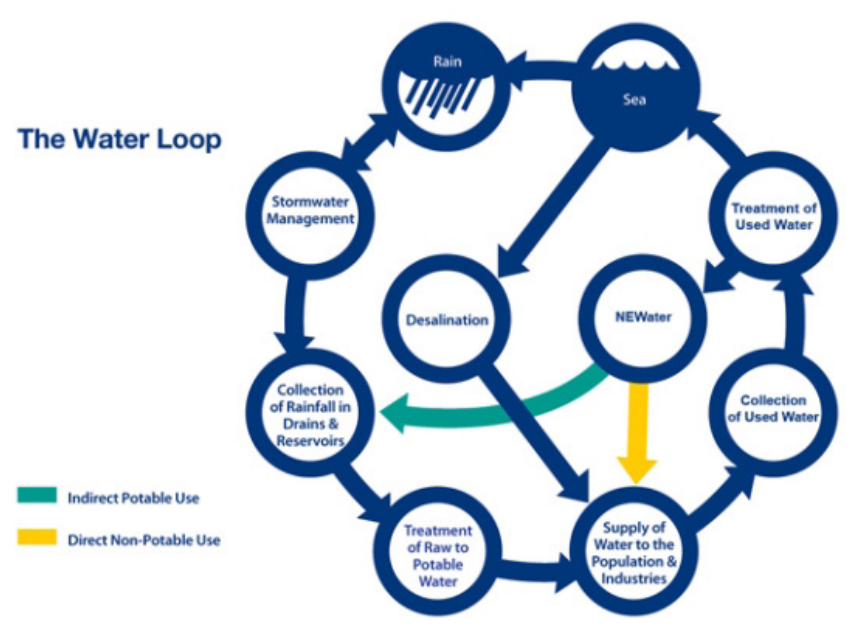

Figure 1 The PUB approach to closing water loop (from http://www.pub.gov.sg/water/Pages/default.aspx).

The first three taps will be described briefly in this paper, but the focus will be on the fourth tap (local catchments). An understanding of Singapore's geography is a necessary prerequisite to fully appreciate the magnitude of the country's efforts in water resource management.

\section{Geography of Singapore}

Singapore is a small island nation-state located at the southern end of the Malaysian Peninsula. It has a total area of $715.8 \mathrm{~km}^{2}$, with an east-west length of only $49 \mathrm{~km}$ and a north-south length of $25 \mathrm{~km}$. At a current total population of 5.3 million (up from 1.6 million in 1960), Singapore's population density of 7257 people/ $\mathrm{km}^{2}$ is ranked the third most dense in the world, after Macau and Monaco. In comparison, the United States ranks 172nd with 34.3 people/ $\mathrm{km}^{2}$ and Canada ranks 220th with 3.8 people/km². Singapore's per capita GDP in 2011 (adjusted for purchasing power parity and based on current international dollars) was higher, at $\$ 60688$ than either the United States (\$48 112) or Canada (\$40 370) according World Bank statistics (http://data.worldbank. org/indicator/NY.GDP.PCAP.PP.CD).

The climate of Singapore is classified under the Koppen system as a tropical rainforest (Af) with no true dry season. Annual mean rainfall is approximately $2343 \mathrm{~mm}$ and annual mean temperature is $27^{\circ} \mathrm{C}$. The annual maximum $60 \mathrm{~min}$ rainfall intensity 1980-2010, ranged between $70 \mathrm{~mm} / \mathrm{h}$ and $130 \mathrm{~mm} / \mathrm{h}$. In keeping with its tropical rainforest classification, the mean number of days/month with rain ranges between 11 and 19, and 
the minimum number of rain days per month is in the range 1 to 3 (http://app2.nea.gov.sg/weather_faq.aspx, http://app2.nea. gov.sg/weather_statistics.aspx). This amount of rainfall, and associated runoff, presents management challenges and eclipses the amounts experienced even in the wettest parts of Florida (1730 mm per year).

\section{The Four National Taps}

\subsection{Water Imports from Malaysia}

As noted previously two water agreements between Malaysia and Singapore were signed in 1961 and 1962, the first of which expired in 2011 and the second of which will expire in 2061. The current (second) agreement still provides up to $250 \mathrm{mgd}$ (1 $137000 \mathrm{~m}^{3} / \mathrm{d}, 13.16 \mathrm{~m}^{3} / \mathrm{s}$ ). This water enters Singapore via a pipeline at the causeway between Singapore and Johor, Malaysia.

Singapore and Malaysia have a long history of water import agreements that stretches back to 1927, and a new round of water negotiations began in 1998 which was linked to economic packages focusing on recovery from the Asian financial crisis (Tortajada and Pobre 2011). By 2003, Singapore had begun to look seriously for alternative water sources, including importing from Indonesia, and ultimately the negotiations with Malaysia ended without agreement (Tortajada and Pobre 2011). With the expiry date of 2061 for the second agreement approaching, this has become the de facto planning horizon for Singapore to advance and diversify its technologies as it moves towards the goal of water self sufficiency.

\subsection{NEWater}

Five NEWater plants now provide $60 \mathrm{mgd}\left(273000 \mathrm{~m}^{3} / \mathrm{d}\right)$, which meets $30 \%$ of Singapore's water demands (Chew et al. 2011), and PUB expects that by 2060 NEWater will meet $50 \%$ of Singapore's demand (http://www.pub.gov.sg/water/newater/Pages/default. aspx). The NEWater plants accept treated wastewater and then further treat the wastewater using a three stage process that includes microfiltration, reverse osmosis and ultra-violet disinfection to produce water that meets U.S. EPA and WHO drinking water standards (Benett 2011). NEWater is used primarily as a replacement for potable water in industrial processing, including microelectronics and wafer fabrication, although a small percentage also is blended into reservoirs for indirect potable use. The NEWater plants are an outstanding example of the innovative research and development that resulted from the combined efforts of government and the private sector (Chew et al. 2011). The NEWater Visitor Centre provides daily guided tours of the plant and includes scale models of the processes and educational opportunities for schools and the public (http://www.pub.gov.sg/ water/newater/visitors/Pages/default.aspx).

\subsection{Desalination}

Once considered a costly last option for water scarce countries, desalination technology has advanced dramatically over the past decade (Bremere et al. 2001; Khawaji et al. 2008; Greenlee et al.
2009). Singapore currently has one seawater reverse osmosis plant that produces $30 \mathrm{mgd}\left(136000 \mathrm{~m}^{3} / \mathrm{d}\right)$ and meets about $10 \%$ of Singapore's water needs (http://www.pub.gov.sg/water/ Pages/DesalinatedWater.aspx). A second $70 \mathrm{mgd}\left(318000 \mathrm{~m}^{3} / \mathrm{d}\right.$ ) desalination plant will be completed in 2013, and by 2060 the desalinated water is expected to meet $30 \%$ of Singapore's demand.

\subsection{Runoff from Local Catchments}

In summary, by 2060 , NEWater is expected to meet $50 \%$ of Singapore's demand and desalination will meet $30 \%$ of the demand. It is possible that water imports from Malaysia will continue past 2061 , but the fourth national tap to consider is collection of stormwater runoff from local catchments.

Stormwater runoff is now captured from two-thirds of Singapore's land area and stored in seventeen reservoirs throughout the island for subsequent use. Furthermore, all major estuaries have been dammed to create reservoirs, and PUB intends to capture water from remaining streams near the shoreline, which will increase Singapore's water catchment area to $90 \%$ by 2060 (http://www.pub.gov.sg/water/Pages/LocalCatchment. aspx). One of the most recent additions to reservoir capacity is the Marina Barrage, which collects runoff from a 10000 ha area having a population of around 1000000 people (Kamer et al. 2008). A $350 \mathrm{~m}$ wide dam separates Marina Bay from the sea, while the bay receives freshwater discharges from the Singapore River, Stamford Canal, Rochor Canal, Sungei Whampoa, Kallang River, Geylang River and Pelton Canal. The barrage also provides flood control for local low-lying areas. Construction of the barrage was completed in 2008 and by 2010 the impoundment had been successfully flushed of seawater and converted to a freshwater reservoir. The Marina Barrage Activity Centre, constructed as part of the pump housing, includes a green roof, solar park, energy and water efficient fixtures (including double glazed glass and natural lighting), a cooling system that uses the reservoir water, and the Sustainable Singapore Gallery that provides educational opportunities about water, the environment and the Marina Barrage operation.

Clearly, it is important, to the extent possible, to maintain stormwater runoff quality and thereby keep treatment costs for drinking water to a minimum. Water quality issues also must be balanced with local flooding issues and therefore stormwater management is of primary concern to PUB. The reservoirs receive discharge from approximately $7000 \mathrm{~km}$ of drains and canals. Khoo (2009) noted that traditionally the canals and drains were covered, and when above ground were simply concrete conduits which resulted in a sense of detachment between people and the waterways. As such, PUB initiated its ABC Program in 2006 to reconnect Singapore's population to its water. The ABC Program includes water based nature areas, but it has also supported extensive research and demonstration projects related to stormwater runoff management and LID technologies (PUB 2011).

A full review of all stormwater management and LID technologies supported under the ABC Program cannot be provided 
in this paper due to space limitations; however the following provides a sense of the diverse and innovative initiatives undertaken by PUB.

\section{Raingardens (Bioretention Cells)}

The first large-scale raingarden was constructed at Balam Estate in 2008. Balam Estate is part of the Housing and Development Board (HDB) of Singapore. a public housing initiative. The raingarden drains an area of 0.6 ha and has an effective stormwater treatment area of $240 \mathrm{~m}^{2}$ (Figure 2). Flow from the raingarden discharges to a local drainage canal. The design of the raingarden is described by Ong et al. (2012), but an important feature is the inclusion of a $0.3 \mathrm{~m}$ thick layer of rock and wood chips that provide anoxic conditions, which appears to enhance nitrogen removal. Ong et al. (2012) also reported the results of monitoring water quality inputs and outputs associated with the raingarden for 6 storms (peak 10 min rainfall intensities of $32 \mathrm{~mm} / \mathrm{h}$ to $84 \mathrm{~mm} / \mathrm{h}$ ) monitored in 2009 and 2010 (Figure 3). The average reductions for total nitrogen (TN), total phosphorus (TP), and total suspended solids (TSS) were $46 \%, 21 \%$ and $57 \%$ respectively, and Ong et al. (2012) suggested the lower percentage reductions were related to low inflow concentrations to begin with. In general, however, the raingarden appears to be performing satisfactorily. PUB (2011) also highlighted 6 other raingarden projects in Singapore under the ABC Program.

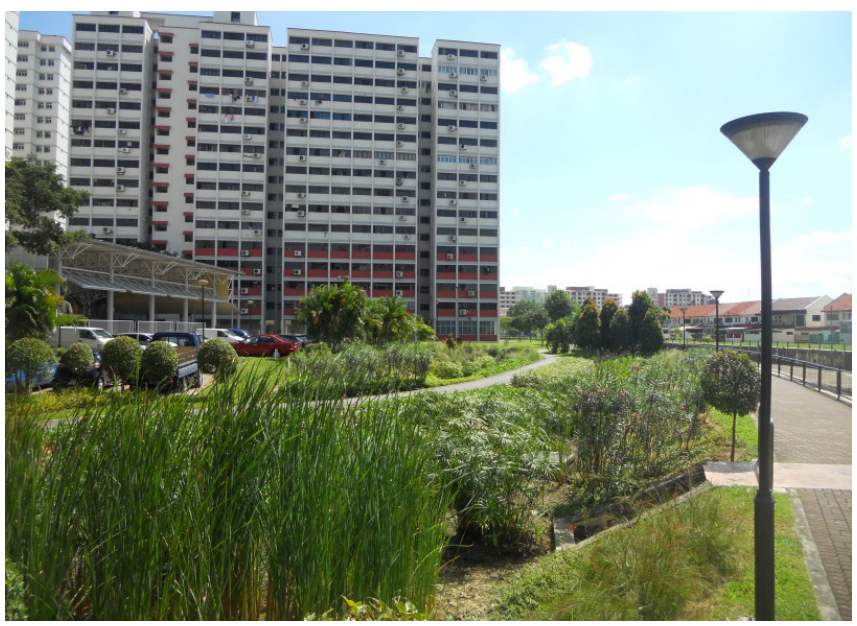

Figure 2 Balam Estate raingarden.

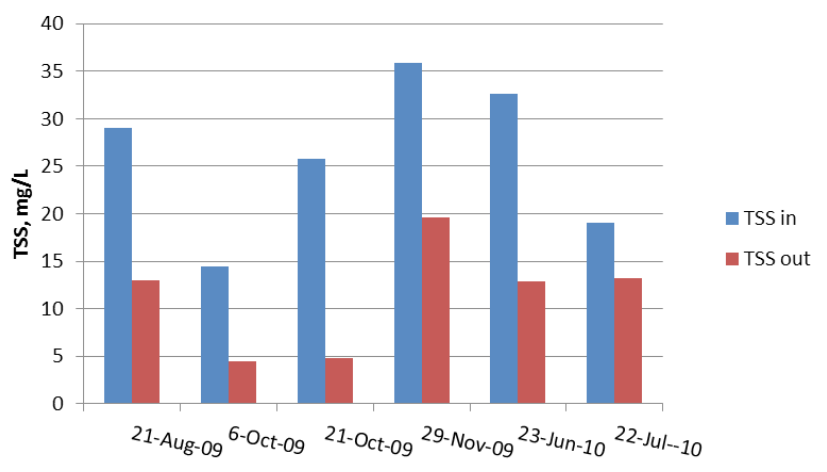

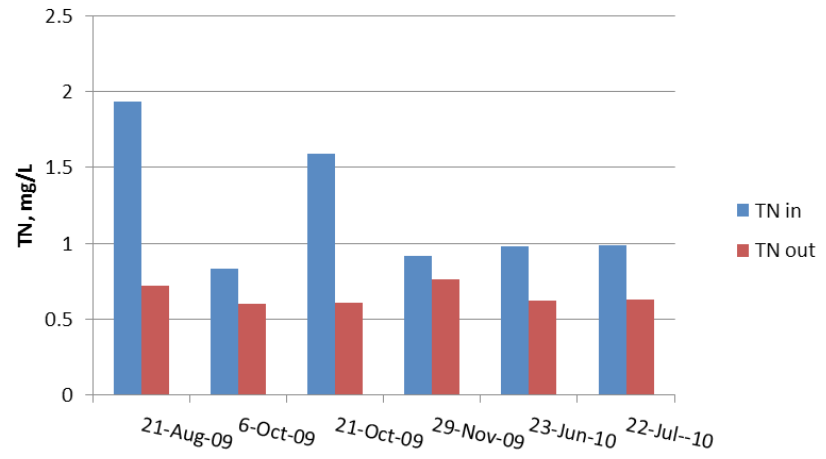

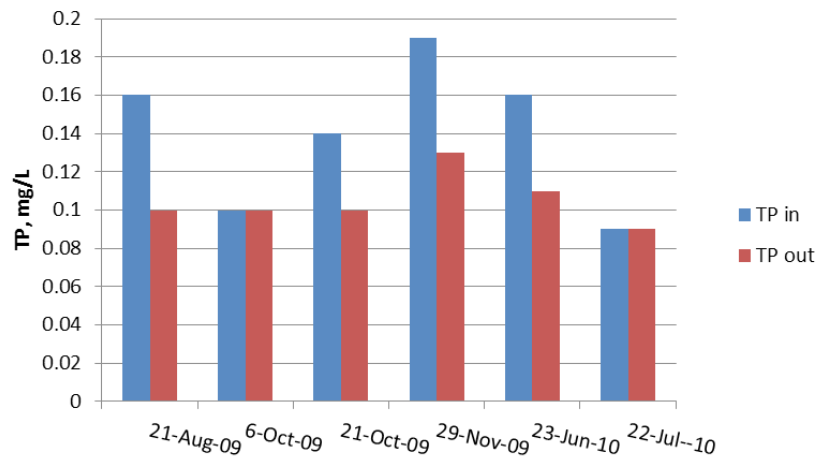

Figure 3 Treatment efficiency of Balam Estates raingarden for 6 sampled events (TSS upper, TN middle, TP lower), data from Ong et al. 2012.

\section{Stormwater Planters}

These have been effectively integrated into the design fabric of major core shopping areas such as Orchard Road (Figure 4).

\section{Pervious Pavement}

Pervious pavement has been installed in the majority of HDB housing estates (which are home to $~ 83 \%$ of Singaporeans, http://www.hdb.gov.sg/fi10/fi10320p.nsf/w/AboutUsPublicHousing), as well as in commercial areas and institutions (Figure 5).

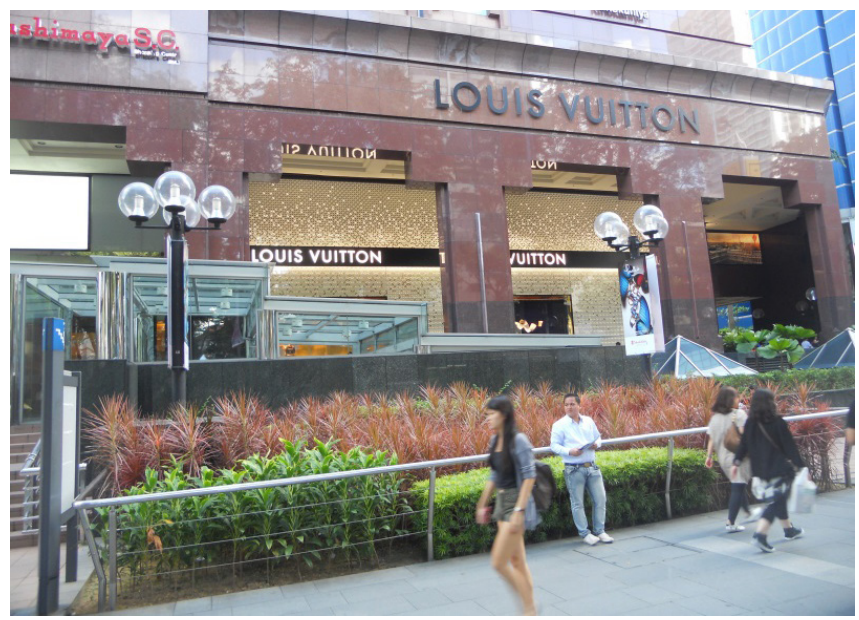

Figure 4 Stormwater planters, Orchard Road. 


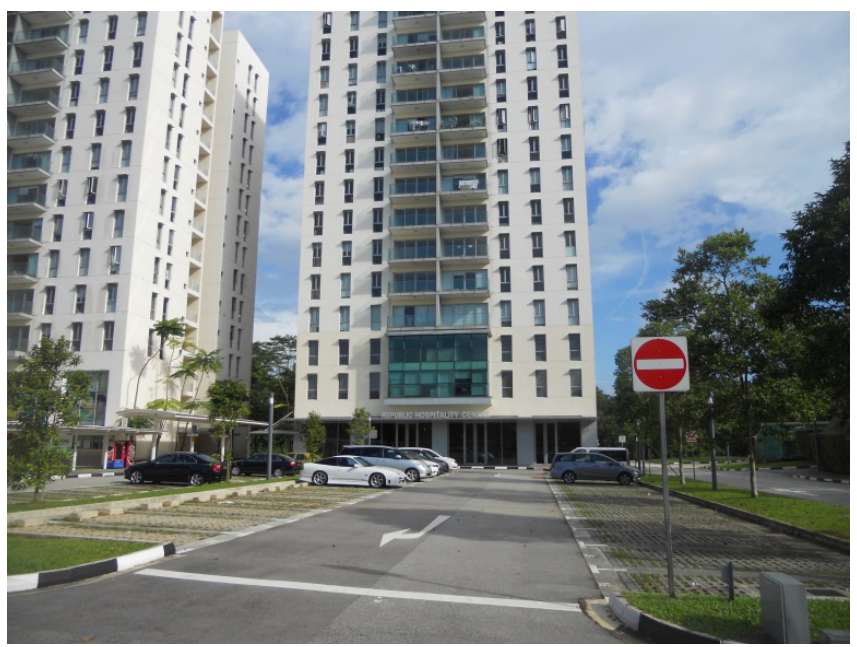

Figure 5 Pervious parking place pavers.

Floating wetlands

Floating wetlands use emergent plants growing on a floating mat on the water surface rather than rooted in the sediments (De Stefani et al. 2011). The plants fixed to the floating substrate platform perform similar functions to a conventional wetland, including physical filtration, dissolved nutrients uptake and support for microorganisms, although in this case the nutrient uptake is hydroponic rather than through the root system growing in sediment (Stewart et al. 2008; De Stefani et al. 2011). One of the advantages of a floating wetland system is that it can adapt to greater fluctuations in water level since the plants are not susceptible to prolonged submergence and drowning. For Singapore, an additional benefit is that floating wetlands can be installed at the existing reservoirs and no new land is needed to construct the wetland. Floating wetlands have been installed at a number of Singapore's reservoirs (Figure 6).

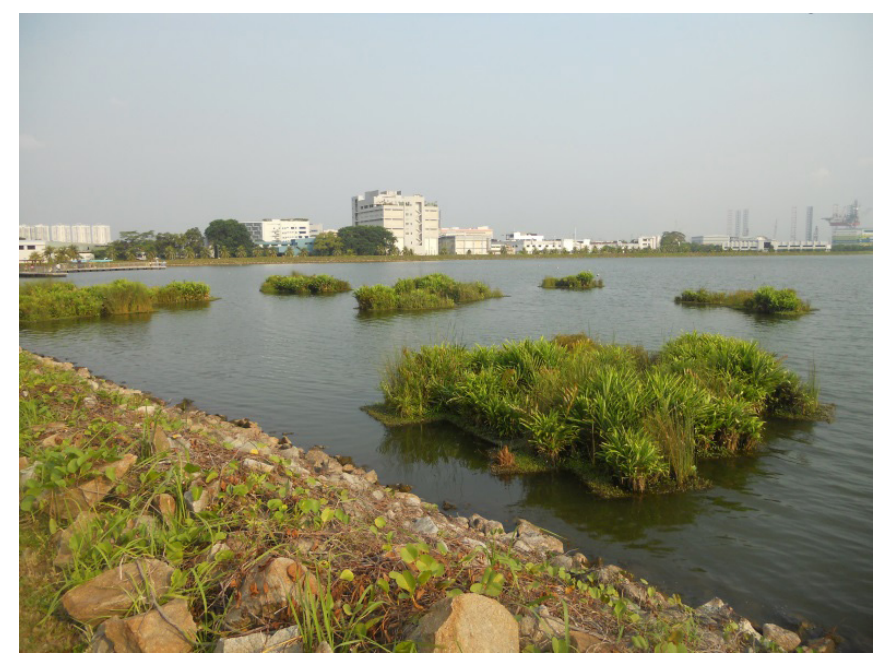

Figure 6 Floating wetlands.

In a recent experimental study for the Kranji Reservoir in north-western Singapore Chua et al. (2012) noted that 50\% removal rates could be obtained for total nitrogen and total phosphorus, but that full implementation would require an excessive mat footprint and the floating wetlands would need to be combined with other measures to be optimally effective. De Stefani et al. (2011) note there are a limited number of studies that have reported treatment efficiencies and therefore studies such as that done by Chua et al. (2012) should be further pursued.

\section{Constructed Wetlands}

Constructed wetlands require minimal technical expertise for maintenance, are cost effective and environmentally friendly. No chemicals are needed for treatment and electricity is not consumed (Koottatep et al. 2005; Paing and Voisin 2005). Technically they are a feasible approach for treatment of stormwater runoff; municipal, industrial and agricultural wastewater; landfill leachate; and faecal sludge (Nielsen 2005; Brix et al. 2007; Kengne et al. 2008; Koottatep and Panuvatvanich 2010). Visoth et al. (2010) summarized wetland treatment efficiencies reported in the literature and found that while performance can vary, the TSS removal was in the $25 \%$ to $86 \%$ range, TP in the $15 \%$ to $75 \%$ range, and TN in the 0 to $55 \%$ range; up to $70 \%$ of total zinc $(\mathrm{Zn})$, copper (Cu), and lead $(\mathrm{Pb})$, also could be removed. Constructed wetlands in various configurations have been installed throughout Singapore (e.g. Alexandra Canal, Larong Halus, Sengkang Riverside Park), and research on small scale neighborhood wetlands is ongoing at Grove Drive (PUB 2011, Figure 7).

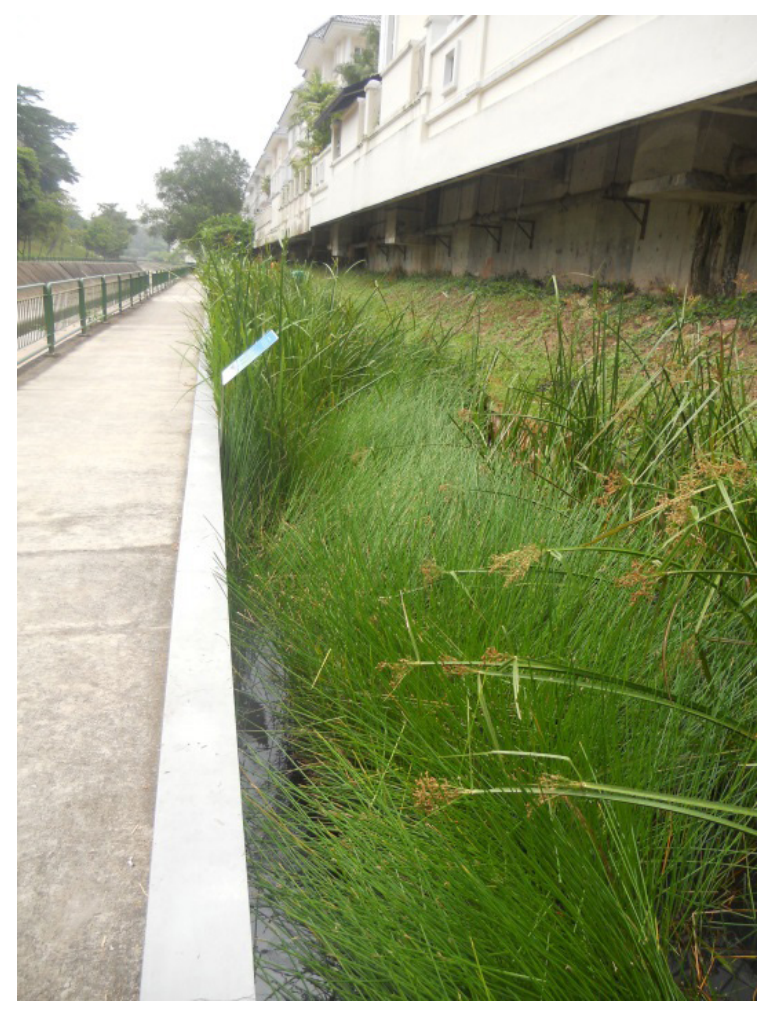

Figure 7 Grove Drive pilot neighborhood constructed wetland. 


\section{Green Roofs and Rooftop Gardens}

Newman (2011) suggested that Singapore has been moving away from its original tag of The Garden City to City in a Garden through a combination of strategies, including the National Parks Board (NParks) Skyrise Greenery initiative that will fund up to $50 \%$ of the installation costs of green roofs and vertical greenery (http:// www.skyrisegreenery.com/index.php/home/incentive_scheme/ about/).

Although not an $A B C$ Waters Program, the potential benefits of green roof technology in runoff control, energy savings, heat island reduction and air quality improvement have been identified (Wong et al. 2003; Li 2008; Stovin 2010; Chen and Li 2011; Rowe 2011), and Singapore's extensive efforts in skyrise greenery is worth noting as an example of PUB's 3P (People, Public and Private) philosophy for water management. In this sense, both the public and private sectors participate in skyrise greenery (Figures 8 and 9).
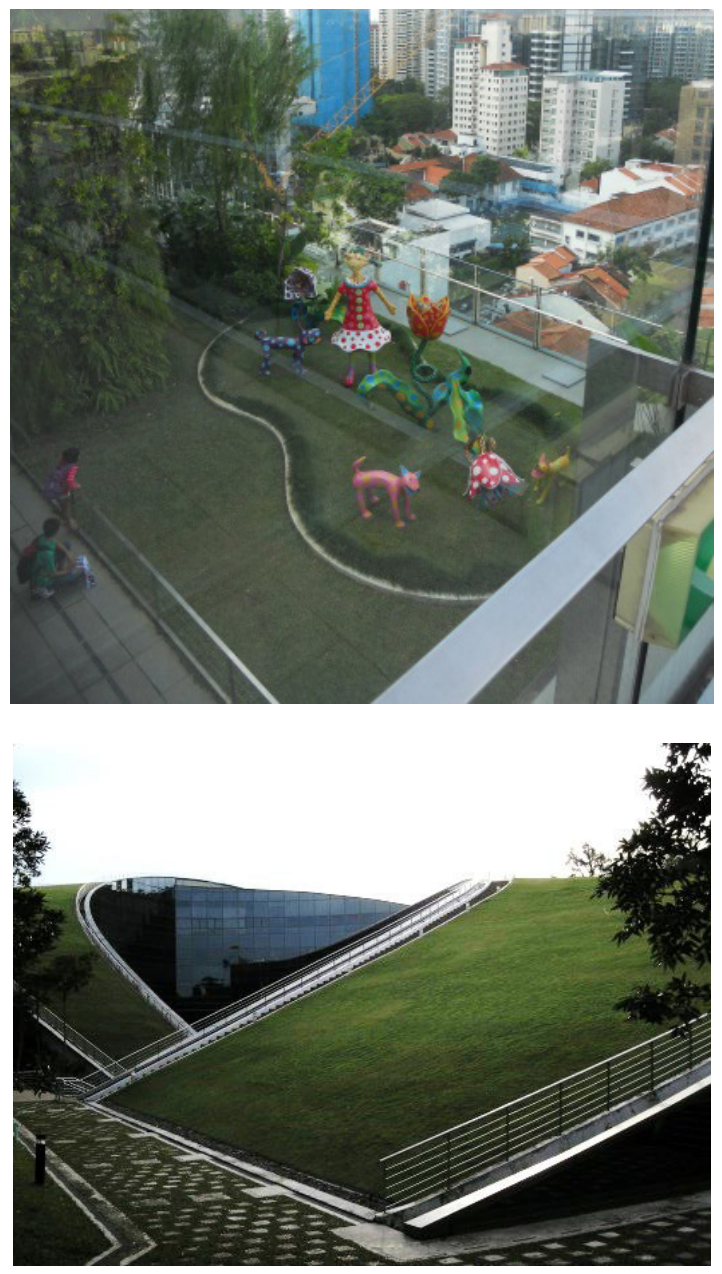

Figure 8 Roof top green play area, Orchard Centre (upper); Green roof, Nanyang Technological University (lower).

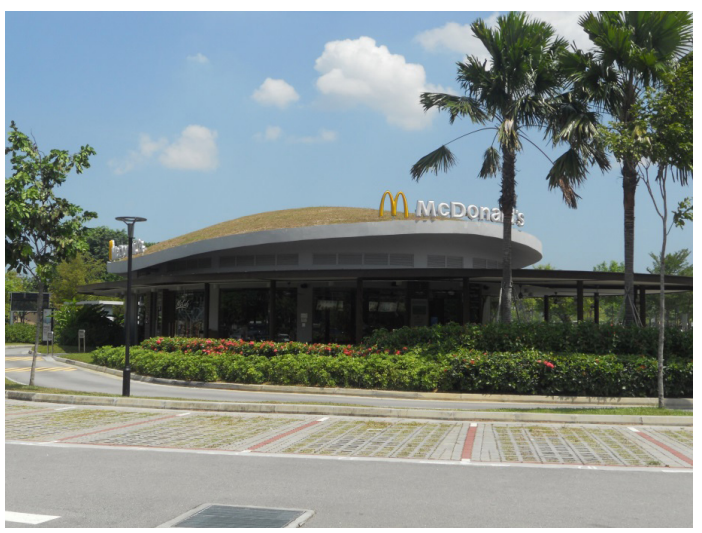

Figure 9 Boon Lay McDonald's with green roof, stormwater planters and pervious paving.

\section{Bishan Park/Kallang River Naturalization Project}

One of the remarkable achievements of the $A B C$ Waters Program was the transformation of $3 \mathrm{~km}$ of the Kallang River in Bishan Park from a concrete drainage canal into a natural channel with meanders, pools and riffles, bioengineered slopes, and a cleansing biotope consisting of 15 cells in 4 terraces (Figure 10). Officially opened in March 2012, with a construction cost of $\$ 60$ million USD, the park has won a number of awards, including a World Architecture Award (2012), an Excellence on the Waterfront Honor Award (2012), and the President's Design Award Singapore (2012) (http://www.landezine.com/index.php/2012/06/kallangriver-at-bishan-ang-mo-kio-park-by-atelier-dreiseitl/).
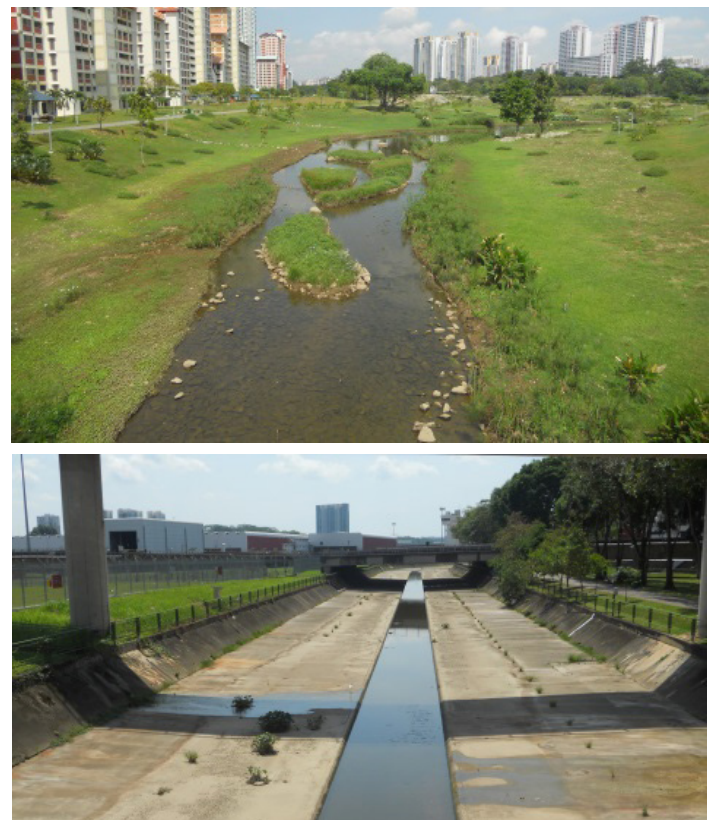

Figure 10 Bishan Park-Kallang River naturalized area (upper) and channelized area (lower), immediately downstream; the naturalized area looked like the downstream area prior to 2009 . 


\section{Results of Pilot Projects}

This section describes the preliminary results of three pilot projects conducted by undergraduate students at the National Institute of Education (NIE), Nanyang Technological University (NTU), as part of the course requirements in AAG103 and AAG333 during the Fall (August-December) semester, 2012. Because these studies were done as part of course requirements, their scope was necessarily limited, but collectively they underscore some of the issues raised in the previous section and suggest avenues for new research.

\subsection{Acceptance of NEWater}

One group of five students in AAG103 (Techniques in Geography) conducted a blind taste test of NEWater (described in Section 3.2) and of tap water from one of the student's HDB apartments, and a questionnaire about acceptance of NEWater was administered at the same time. The survey was conducted on the NIE campus and the 60 participants included students, faculty, and non-technical staff, such as cleaners and food stall vendors.

A Mann-Whitney $U$ test indicated participants preferred the taste of NEWater compared to the tap water sample $(a=0.05)$. Furthermore, a Spearman Rank Correlation showed a significant correlation ( $a=0.05$ ) between the level of understanding about NEWater and the level of acceptance that NEWater would become the main source of drinking water. Only $18 \%$ of those surveyed expressed an unwillingness to accept NEWater as part of their tap water for every day use. Ching (2010) conducted an analysis of 223 newspaper articles for the period 1997-2008 and concluded that Singaporean news media had followed a rational, pro-policy approach in delivering messages about NEWater that had helped with its public acceptance.

\subsection{Understanding of Stormwater Management Issues}

One group of eight students in AAG333 (Resource and Environmental Management) conducted a survey of 50 randomly selected people who were using Bishan Park (walking, exercising or relaxing) within the area of the naturalized Kallang River, described in Section 4.4. The results showed that $60 \%$ of the survey participants were unaware of the ABC Waters Program that had been implemented in Bishan Park (i.e. the reason for the naturalization and greening). Furthermore, $66 \%$ of the participants felt they did not have a good understanding about stormwater management and $36 \%$ of the participants disagreed with the statement "Animal waste and soapy water from car washing are pollutants", while an additional $4 \%$ were unsure about the statement. Similar percentages also disagreed that runoff from yards, parking lots and streets could be a source of pollution.

\subsection{Dry Weather Runoff Quality}

Given the high-density development of Singapore and associated anthropogenic activities, high rainfall volumes resulting in extended periods of dry weather infiltration, and the collection of urban runoff in drinking water reservoirs, there is some interest in examining bacteria levels in dry weather flow. As such, two groups of students in AAG333 collected and analyzed dry weather samples in the storm drains of the Toa Payoh urban planning region, which is one of the first HDB estate areas constructed in Singapore.

Samples were collected hourly on 8-9 October, 2013 in the storm drains of Toa Payoh Lorong 6 and Toa Payoh Lorong 8 using Isco pump samplers and were kept on ice in the field at $4{ }^{\circ} \mathrm{C}$. Samples were analyzed for E. coli using the IDEXX QuantiTray/2000 MPN method (IDEXX 2007; Chua et al. 2010) at the NIE Life Sciences Laboratory.

Results of the sampling effort are shown in Figure 11. Because additional tests that had limited reagent availability were being conducted on the water, sample hours 05:00 to 10:00 on 9 October were not analyzed. E. coli levels at Toa Payoh Lorong 6 (geometric mean of $137400 \mathrm{MPN} / 100 \mathrm{~mL}$ ) were consistently higher than at Toa Payoh Lorong 8 (geometric mean of $12800 \mathrm{MPN} / 100 \mathrm{~mL}$ ). At both sites it appeared that the $E$. coli levels were highest in the evening, 20:00 to 24:00 and lower in the midday, 11:00 to18:00.

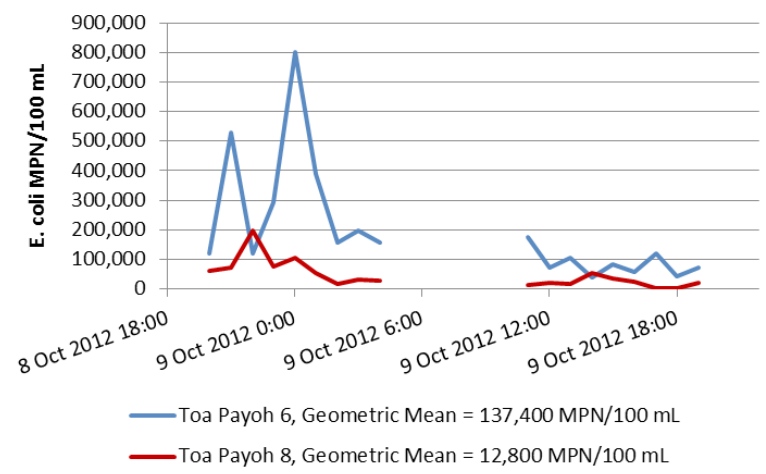

Figure 11 E. coli levels for Toa Payoh Lorong 6 and Toa Payoh Lorong 8 sample sites.

The Toa Payoh Lorong 8 drainage area primarily is residential land use with a peripheral fringe of light industry, while Toa Payoh Lorong 6 includes residential land use, but also a busy commercial area and light industry. The difference in land use and anthropogenic activity may account for the higher $E$. coli levels at Toa Payoh Lorong 6, although this would need to be investigated in more detail. Interestingly, the students observed that at Toa Payoh Lorong 6 when the rubbish chutes and compaction bins for the apartments were being cleaned (which could include, for example, disposable diapers), the workers disposed of the washwater directly into the drains. Chua et al. (2010) reported E. coli levels in storm drains for sites in the Kranji Reservoir watershed generally to be in the $1000 \mathrm{MPN} / 100 \mathrm{~mL}$ range, with extremes of 1000000 MPN/100 mL. Maximum values from Toa Payoh Lorong 6 were similar to those reported by Chua et al. (2010), although on average both Toa Payoh Lorong 6 and Lorong 8 E. coli levels 
were higher than the Kranji sites. Results suggest that more work could be done to improve urban runoff quality, but it must be emphasized that Singapore is an urban area that is subject to anthropogenic activities and that the water from the reservoirs is rigorously treated before it is distributed to the tap.

\section{Conclusions}

Singapore has made remarkable strides in developing an advanced, innovative, and effective approach to water management. The question is, What factors led to this management system? There seem to be at least eight factors that have combined to facilitate the evolution of the current water management system:

1. Need With the uncertainty of pricing and continued water imports from Malaysia, there was an impetus to become self sufficient with respect to water;

2. Leadership and Vision Starting with the philosophy of Singapore's first Prime Minister, Lee Kuan Yew, of a garden city, that has now evolved into a city in a garden, the leadership in Singapore consistently has developed the water management system in the interest of public good;

3. Political Will In addition to leadership, the political structure and stability need to be in place to understand the importance of water and to have the ability to support water resource development. Leitmann (2000) noted that Singapore successfully balanced rapid economic development and environmental quality by employing a number of effective practices including regulatory measures, planning controls, economic incentives, and public education campaigns. In this sense, Singapore has utilized its small size to its advantage as it is possible to more efficiently focus highly concentrated human and urban infrastructure resources;

4. Economic Capacity As noted, Singapore has a robust and strong economy and certainly some of the initiatives, such as the naturalization of the Kallang River, require significant economic commitment;

5. Single Lead Agency PUB is the primary agency responsible for water resource management (in consultation with other government agencies such as NParks and HDB) and management has taken on a holistic, hydrologic cycle approach. This maximizes efficiency in decision making and reduces issues of confusion (and sometimes competition) from overlapping mandates;

6. Openness to New Ideas From the time Sir Stamford Raffles established Singapore as a port open to all countries, Singapore has embraced a philosophy that uses and adapts ideas from a multicultural milieu. This tradition has facilitated a willingness to test new stormwater technology approaches;
7. Education Singapore has high education expectations, particularly in math and science, and consistently has ranked first or second in the Grade 8 Trends in International Mathematics and Science Study (TIMMS, http://nces.ed.gov/Timss/) administered globally since 1995 . Olds (2007) noted that the evolution of science and technology policy in Singapore followed three phases: 1965 to 1986, building technological know-how; 1985 to 1995 , expanding science and technology education; and 1995 to 2005, fostering creativity and innovation. Tortajada and Joshi (2013) observed that the Singaporean school curriculum has played a central role in educating future generations with respect to water and the environment. For example, in 1987 a water conservation course was introduced at the secondary level to explain Singapore's water challenges and the importance of conservation;

8. Public-Private Partnerships Such partnerships were particularly important in refining the NEWater and desalination technologies. Olds (2007) concluded that Singapore has embraced a shift to a knowledge based economy where there is a need for "Enhanced and diversified services and high valued added manufacturing sectors, as well as better educated and more skilled citizen subjects; creative souls that would contribute to contemporary and especially future developments." Clearly this philosophy links back to point 7, but as noted by Olds (2007), the Economic Development Board's Industry 21 strategy emphasizes:

... manufacturing and service industries with a strong emphasis on technology, innovation and capabilities. We also want to leverage on other hubs for ideas, talents, resources, capital and markets. The knowledge-based economy will rely more on technology, innovation and capabilities to create wealth and raise the standard of living. For our knowledgebased economy to flourish, we will need a culture which encourages creativity and entrepreneurship, as well as an appetite for change and risk-taking.

While Singapore has a remarkable water resource management strategy, and Singaporeans seem to embrace the technologies such as NEWater (e.g. the survey results of the NIE class), there always is a need for continual assessment and improvement. Tortajada and Joshi (2013) underscore this point, commenting "Overall, long-term conservation efforts have been positive, but they have required vast and sustained efforts of the water agency to remind the public once and again on the importance of water conservation." In particular, while PUB has an excellent website, established an innovative Waters Learning Trails Program (a series of eleven place-based trails that provide hands-on learning experiences with respect to the $A B C$ Waters Program), and has a well developed public outreach program, the 
NIE survey suggests there is an ongoing need to work with the public to improve their understanding of stormwater management issues. Singapore's universities have an essential role to play as part of this effort. One of NIE's prime mandates is pre-service teacher education through a combination of pedagogy and content and it is important to strengthen the connections between water, environment, and society with these future teachers. For example, as part of the course AAG332 (Ecosystem Dynamics) offered in 2013, students were trained to be guides at one of PUB's Waters Learning Trails sites, provided guide service to select schools, and developed their own lesson plans focusing on the Trails' themes. It is expected that the lesson plan development will perpetuate itself once these pre-service teachers enter the profession and a fuller understanding of water management will be infused in future generations to an even greater extent. PUB staff also provided guest lectures to the class on water management philosophy in Singapore and efforts in developing biological indicator systems for ecosystem assessment. A number of undergraduate students doing their final year projects at NIE and in Environmental Engineering at NTU are working on our PUB- and NParks-supported projects looking at the longitudinal change of water quality in the Kallang River (and including the naturalized Bishan Park) and modelling water quality in a local park treatment train of a rain garden and detention pond. This type of government agency-academic institution collaboration under the education rubric needs to be aggressively pursued, because students take a more active interest in studies that have a real world relevance. WaterWorld reports the National University of Singapore and NTU recently were ranked first and second, globally, in water research (http://www.topuniversities.com/qs-world-universityrankings). The ability to do leading basic and applied research clearly exists. The Nanyang Environment and Water Research Institute (NEWRI) at NTU, for example, was established in 2008 to provide a focal point for research and new applications in the environmental and water industry, with the intent of grooming capacity to strengthen Singapore's global standing in the field. NEWRI connects faculty with both the public and private sectors, and also has a philanthropic mission related to capacity-building in developing countries of Asia. These types of multidisciplinary, transdisciplinary, collaborations are essential in continuing along the path of sustainable water resource development that Singapore has demonstrated over the past several decades.

\section{Acknowledgments}

Thanks to the students from AAG103 and AAG333 for their hard work in conducting their class projects, specifically Cher Huey Min, Joo Chan Hock Joseph, Lee Si Xian, Lydia Lee Wei En, Ng Gek Lee Bernice, Kelvin Su Wei Jie, Ng Yun Wen Arica, Feng Hui'er, Lim Kian Long, Ong Kheng Loon, Chan Jia Kun Jason, Chia Hui Lin, Loon Jia Hui Bernice, Rossellini Tan Yeling, Loh Shi Ting, Lam Yao Lun, Goh Chiat Yi Crystal, Xie Yifang, Mansoor Bin Abdul, Ang Yen Qing Joyce, Faizul Nisha D/O Vappriah Abdul Kader, Lim Mui
Huay, Nurfaizah Binte Ismail, Rozianah Binte Rosli, and Sng Jie Ling Steffi.

This work was done while Kim Irvine was on sabbatical at National Institute for Education, Nanyang Technological University, Singapore. The IDEXX system for E. coli analysis was provided by the Environmental Engineering program at Nanyang Technological University. Thanks to Dr. Sam Choon Kook and Mr. Ho Wai Chai, NSSE, NIE, for providing the Life Science Laboratory facilities. Very special thanks to Eveline Ekklesia for organizing the AAG333 fieldwork in Toa Payoh and overseeing the E. coli analysis.

\section{References}

Ang, C. G. 2013. Lee Kuan Yew's Strategic Thought. New York: Routledge.

Bennett, A. 2011. “Potable Water: New Technology Enables Use of Alternative Water Sources." Filtration+Separation (March/ April): 24-7.

Bremere, I., M. Kennedy, A. Stikker and J. Schippers. 2001. How Water Scarcity Will Effect the Growth in the Desalination Market in the Coming 25 Years." Desalination 138:7-15.

Brix, H., H. H. Schierup and C. A. Arias. 2007. "Twenty Years Experience with Constructed Wetland Systems in Denmark: What Did We Learn?" Water Science and Technology 56 (3): 63-8.

Chang, J. H. Y. 2003. "Culture, State and Economic Development in Singapore." Journal of Contemporary Asia 33 (1): 85-105.

Chen, J. and J. Li. 2011. "Characterization of Green Roof Stormwater Runoff Quality." Journal of Water Management Modeling R241-18. doi: 10.14796/JWMM.R241-18.

Chew, Y. C. M., C. Watanabe and Y. Tou. 2011. “The Challenges in Singapore NEWater Development: Co-Evolutionary Development for Innovation and Industry Evolution."Technology in Society 33:200-11.

Ching, L. 2010. “Eliminating 'Yuck': A Simple Exposition of Media and Social Change in Water Reuse Policies." Water Resources Development 26 (1): 111-24.

Chua, L. H. C., P. Shanahan, E. Y. M. Lo, E. B. Shuy, J. Thompson, C. C. Dixon, K. B. Kerigan, J. P. Nshimyimana, J. M. Yeager, L.-J. Lee and Y.-L. Por. 2010. “Dry Weather Bacteria Monitoring and Variation with Land Use for Kranji Reservoir Catchment." In Proceedings of the 17th Congress of the Asia and Pacific Division of the International Association of Hydraulic Engineering and Research, Auckland, New Zealand. Singapore: IAHR (International Association for Hydro-Engineering and Research).

Chua, L. H. C., S. B. K. Tan, C. H. Sim and M. K. Goyal. 2012. “Treatment of Baseflow from an Urban Catchment by a Floating Wetland System." Ecological Engineering 49:170-80.

De Stefani, G., D. Tocchetto, M. Salvato and M. Borin. 2011. “Performance of a Floating Treatment Wetland for In-Stream Water Amelioration in NE Italy." Hydrobiologia 674:157-67. 
Goh, A. L. S. 2005. “Towards An Innovation-Driven Economy Through Industrial Policy-Making: An Evolutionary Analysis of Singapore." The Innovation Journal: The Public Sector Innovation Journal 10 (3): 1-32.

Greenlee, L. F., D. F. Lawler, B. D. Freeman, B. Benoit Marrot and P. Moulin. 2009. “Reverse Osmosis Desalination: Water Sources, Technology, and Today's Challenges." Water Research 43:2317-48.

Huff, W. G. 1987. "Patterns in the Economic Development of Singapore." The Journal of Developing Areas 21 (3): 305-26.

IDEXX. 2007. Colilert Test Kit. Westbrook, ME: IDEXX Laboratories.

Ismail, S.-H. 2012. "'Second Colonial Occupation': The United States and British Malaya 1945-1949." Asian Culture and History 4 (1): 29-40.

Joshi, Y. K., C. Tortajada and A. K. Biswas. 2012. “Cleaning of the Singapore River and Kallang Basin in Singapore: Economic, Social, and Environmental Dimensions." Water Resources Development 28 (4): 647-58.

Kamer, J., R. Thomson, T. Mackenzie, L. K. Ooi and B. C. Phillips. 2008. "Investigating Sewer Rehabilitation in the Marina Reservoir Catchment in Singapore." In 11 ICUD: 11th International Conference on Urban Drainage, Edinburgh, Scotland. IAHR/IWA. http://www.11icud.org.

Kengne, I. M., A. Akoa, E. K. Soh, V. Tsama, M. M. Ngoutane, P. H. Dodane and D. Kone. 2008. "Effects of Faecal Sludge Application on Growth Characteristics and Chemical Composition of Echinochloa pyramidalis (Lam.) Hitch. and Chase and Cyperus papyrus L." Ecological Engineering 34:233-42.

Khawajia, A. D., I. K. Kutubkhanaha and J.M. Wie. 2008. “Advances in Seawater Desalination Technologies." Desalination 221:47-69.

Khoo, T. C. 2009. "Singapore Water: Yesterday, Today and Tomorrow." In Water Management in 2020 and Beyond, edited by A. K. Biswas et al., 237-50. Berlin: Springer-Verlag.

Koottatep, T. and A. Panuvatvanich. 2010. “Constructed Wetlands for Effective Wastewater Treatment." In Water Resources and Development in Southeast Asia, edited by K. Irvine, T. Murphy, V. Vanchan and S. Vermette, 179-92. Boston, MA: Pearson Custom Publishing.

Koottatep, T., N. Surinkul, C. Polprasert, A. S. M. Kamal, D. Kone, A. Montangero, U. Heinss and M. Strauss. 2005. "Treatment of Septage in Constructed Wetlands in Tropical Climate: Lessons Learnt from Seven Years of Operation." Water Science and Technology 51:119-26.

Krugman, P. 1994. "The Myth of Asia's Miracle." Foreign Affairs 73 (6): 62-78.

Leitmann, J. 2000. Integrating the Environment in Urban Development: Singapore as a Model of Good Practice, Urban and Local Government Working Paper Series, 7. Washington, DC: World Bank.

$\mathrm{Li}, \mathrm{J} .2008$. "Modeling the Stormwater Benefits of Green Roofs in the City of Toronto." Journal of Water Management
Modeling R228-17. doi: 10.14796/JWMM.R228-17.

Liu, J. H., B. Lawrence, C. Ward and S. Abraham. 2002. "Social Representations of History in Malaysia and Singapore: on the Relationship Between National and Ethnic Identity." Asian Journal of Social Psychology 5:3-20.

Low, K. C. P. 2011. "Lee Kuan Yew and his Key Leadership Ways.” Business Journal for Entrepreneurs 2011 (2): 50-62.

Murfett, M. H., J. N. Miksic, B. P. Farrell and M. S. Chiang. 1999. Between Two Oceans: A Military History of Singapore from First Settlement to Final British Withdrawal. Oxford: Oxford University Press.

Newman, P. 2011. Green Urbanism and its Application to Singapore, Asia Research Institute Working Paper Series No. 151. Singapore: National University of Singapore.

Nielsen, S. 2005. "Sludge Reed Bed Facilities: Operation and Problems." Water Science and Technology 51 (9): 99-107.

Oei, A. 1998. What If There Had Been No Lee Kuan Yew? Singapore: Heinemann.

Olds, K. 2007. “Global Assemblage: Singapore, Foreign Universities, and the Construction of a 'Global Education Hub." World Development 35 (6): 959-75.

Ong, G. S., G. Kalyanaraman, K. L. Wong and T. H. F. Wong. 2012. "Monitoring Singapore's First Bioretention System: Rain Garden at Balam Estate." In WSUD 2012: Water Sensitve Urban Design; Building the Water Sensitve Community, Seventh International Conference on Water Sensitive Urban Design, 21-23 February 2012, Melbourne Cricket Ground, 601-8. Barton, ACT: Engineers Australia.

Ong, I. B. L. 2010. “Singapore Water Management Policies and Practices." International Journal of Water Resources Development 26 (1):65-80.

Paing, J. and J. Voisin. 2005. “Vertical Flow Constructed Wetlands for Municipal Wastewater and Septage Treatment in French Rural Area." Water Science and Technology 51 (9): 145-55.

PUB. 2011. ABC Waters Design Guidelines, 2nd ed. Singapore: PUB (Public Utility Board). http://www.pub.gov.sg/ABCWATERS/ Pages/default.aspx.

Rowe, D. B. 2011. "Green Roofs as a Means of Pollution Abatement." Environmental Pollution 159:2100-10.

Siddiqui, K. 2010. "The Political Economy of Development in Singapore." Research in Applied Economics 2 (2): 1-31.

Stewart, F. M., T. Mulholland, A. B. Cunningham, B. G. Kania and M. T. Osterlund. 2008. “Floating Islands as an Alternative to Constructed Wetlands for Treatment of Excess Nutrients from Agricultural and Municipal Wastes: Results of Laboratory-Scale Tests." Land Contamination \& Reclamation 16 (1): 25-33.

Stovin, V. 2010. "The Potential of Green Roofs to Manage Urban Stormwater." Water and Environment Journal 24:192-9. 
Tan, K. W. 2006. "A Greenway Network for Singapore." Landscape and Urban Planning 76:45-66.

Tortajada, C. and K. Pobre. 2011. “The Singapore-Malaysia Water Relationship: An Analysis of the Media Perspectives." Hydrological Sciences Journal 56 (4):597-614.

Tortajada, C. and Y. K. Joshi. 2013. “Water Demand Management in Singapore: Involving the Public." Water Resources Management 27 (8): 2729-48.

Trocki, C. A. 2006. Singapore Wealth, Power and the Culture of Control. New York: Routledge.

K. N. Irvine Buffalo State, The State University of New York, Buffalo, NY/Nanyang Technological University, Singapore.

L. H. C. Chua Nanyang Technological University, Singapore.

Hans S. Eikass Public Utilities Board, Singapore.
Turnbull, C. M. 1980. A History of Singapore, 1819-1975. Oxford: Oxford University Press.

Visoth, T., M. Yim, S. Vathna, K. Irvine and T. Koottatep. 2010. Efficiency of Phnom Penh's Natural Wetlands in Treating Wastewater Discharges. Asian Journal of Water, Environment and Pollution 7 (3): 39-48.

Wong, N. H., D. K. W. Cheong, H. Yan, J. Soh, C. L. Ong and A. Sia. 2003. "The Effects of Rooftop Garden on Energy Consumption of a Commercial Building in Singapore." Energy and Buildings 35:353-64 